\section{MilitaryTechnicalCollege Kobry El-Kobbah, Cairo, Egypt}

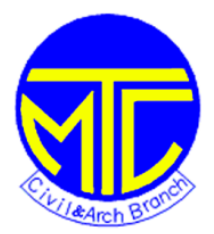

$10^{\text {th }}$ International Conference on Civil and Architecture Engineering

ICCAE-10-2014

\title{
EXPERIMENTAL AND ANALYTICAL BEHAVIOR OF ECONOMICALLY REACTIVE POWDER REINFORCED CONCRETE BEAMS
}

\author{
Nageh N. Meleka ${ }^{1}$, Alaa A. Bashandy ${ }^{* 1}$, Mohamed A. Arab ${ }^{2}$ \\ ${ }^{1}$ Department of Civil Engineering, Faculty of Engineering, Menoufia University, Egypt. \\ ${ }^{2}$ Department of Civil Engineering, Faculty of Engineering, Banisweef University, Egypt.
}

\begin{abstract}
A study for the load deflection behavior of reinforced beams cast using reactive powder concrete RPC-as an ultra high strength concrete type- was executed experimentally and analytically. The experimental program was carried out to study the effect of cement content, using steel fiber and using two types of reinforcement. Results show positive effect on cracking and ultimate loads of reactive concrete beams due to increasing of the cement content. The ductility of the reactive concrete beams is increased by using steel fibers. An analytical study was performed using a nonlinear computer program based on finite element technique. A comparison between analytical and experimental results was carried out to evaluate the efficiency and the accuracy of the used nonlinear computer program. The computer program results were practically close enough to the experimental results. The numerical analysis with the chosen finite element technique presented a good simulation to the RPC beams.
\end{abstract}

Keywords: Reactive Powder Concrete; Ultra High Strength Concrete; Cement Content; Steel Fibres; Reinforcement type; Nonlinear Computer Program; Beam.

\section{INTRODUCTION}

The Reactive Powder Concrete (RPC) is considered as ultra high strength concretes UHSC (Xiaoa et al, 2004) [1]. RPCs exhibit very high mechanical and durability properties. RPC has compressive strengths of 170 to $230 \mathrm{MPa}$ and flexural strength of 30 to $50 \mathrm{MPa}$, depending on the type of fibers used (Moallem, 2010) [2]. Additionally, it has a tensile strength of between 6 and 13 MPa that is maintained after first cracking. The traditional concrete has tensile strengths on the order of 2 to 4 MPa that is lost when cracking occurs (Washer et al, 2003) [3]. It has also an increased resistance to abrasion, erosion, corrosion and greatly reduced permeability to moisture, chlorides and chemical attack (Moallem, 2010) [2].

Ultra high strength concretes are characterized by high silica fume content and a very low water to cement ratio. Granulometry and heat treatment have been optimized to obtain excellent mechanical and durability properties. Their composition is ordinary Portland cement OPC, silica fume, aggregates with very fine granulometry sand with average grain diameter of $250 \mu \mathrm{m}$, crushed quartz (average grain diameter of $10 \mu \mathrm{m})$. Metallic fibers can be added in order to increase concrete ductility and flexural strength (Cheyrezy et al, 1995; JSCE No. 9, 2006) [4-6]. 


\section{Proceedings of the $10^{\text {th }}$ ICCAE-10 Conference, 27-29 May, 2014 MQC-5}

Silica fume (SF) in a concrete mix enhances compressive strength and abrasion resistance while reducing permeability and thus improving resistance against the corrosion of reinforcement. It fills the voids remaining between cement and quartz powder particles as micro filler (Shihada and Arafa, 2010) [7]. Using SF more than $10 \%$ of the cement weight is used to 'refine' the particle structure and thereby reduce the total pore volume and the average pore size. The size and spherical geometry of SF particles allow them to fill effectively the voids between the larger and angular cement grains (Rashid and Mansur, 2009; AL-Hassani et al., 2014) [8, 9]. SF also reacts with calcium hydroxide, thus increasing the final strength. Another important effect of the SF is the improvement of the interfacial transition zones between binder and aggregates and between binder and steel fibers (Habel et al, 2006) [10]. Chemically, it reacts with Calcium Hydroxide $(\mathrm{CH})$ to produce additional Calcium Silicate Hydrate (C-S-H). The reaction between hydrated Portland cement compounds and Silica fume produces a very dense microstructure and thus improves the bond between the cement and the aggregates (Shihada and Arafa, 2010) [7].

In a typical RPC mixture design, the least costly components of conventional concrete have been basically eliminated or replaced by more expensive elements. The fine sand used in RPC becomes equivalent to the course aggregate of conventional concrete, the Portland cement fills the role of the fine aggregate and the silica fume that of the cement (Jooss, 2001; Matte and Moranville, 1999) [11, 12]. Steel fibers enhance the performance of RPC and it can achieve remarkably flexural strength (Orgass, 2004) [13].

Studying the performance of reinforced RPC and UHSC beams were conducted by a few researchers [14-18]. They addressed the outlines of behavior of UHSC under the flexure and shear loads.

Simulating reinforced concrete by using finite element is a complicated process due to the variations in material properties. A suitable material model in the finite element model should inevitably be capable of representing both the elastic and plastic behavior of concrete elements in compression and tension. There are quite a large number of numerical material models available in the literature with the potential to develop complete stress-strain curves of concrete for compression and tension separately based on the experimental results.

In this research, beside the experimental program, a FE program by Meleka (1995) [20] is used to model the behavior of RPC reinforced concrete beams. A comparison between the results of the finite element model and experimental results on RC beam elements was performed in the following study.

\section{RESEARCH SIGNIFICANCE}

This study is carried out to investigate the behavior of reactive powder concrete beams using locally and economically available materials in North Sinai, Egypt. In this research, the available sand with its suitable size to this type of concrete is used despite of using expensive materials such as quartz powder to produce comparable mixtures as most researchers do. This research is also evaluates and analyzes the effect of using different cement and silica fume content. The main variables in this investigation are; cement content, silica fume content, plain or fibrous mixes, renforcement type. Failure loads, deflections at different loading stages as well as propagation of cracks for the tested beams are recorded.

The importance of this research is based on the need to know the available data addressing the behavior of reactive powder concrete beams with its ultra mechanical properties using economical materials. This research provides data for researchers concerning the behavior of ultra high strength reinforced concrete beams.

\section{EXPERIMENTAL PROGRAM}

The conducted experimental program includes the tests carried out on different materials used for casting the reinforced ultra high strength concrete samples and beams as well as the tests performed on samples are shown in this section. 


\subsection{Concrete Materials}

All tests in this research were carried out in the Construction Materials Laboratory in Civil Engineering Department, Faculty of Engineering Science, Sinai University.

The cement used was ordinary Portland cement CEM I N52.5, provided by Sinai cement factory. It satisfy the Egyptian Standard Specification (E.S.S. 4756-1/2009) [21].

The fine aggregate used was the natural siliceous clean and nearly free from impurities sand with a specific weight of $2.66 \mathrm{t} / \mathrm{m}^{3}$. It was obtained from El-Arish City in North Sinai, Egypt. Its maximum nominal size $(0.6 \mathrm{~mm})$ is suitable to be used in casting reactive powder concrete as ultra high strength concrete UHSC. Physical properties of the used sand are given in Table (1) and its grading is shown in Table (2) and Fig. (1). Sand was sieved over sieve of size $0.6 \mathrm{~mm}$ to discard any impurities.

The water used is clean, drinkable, fresh and free from impurities tap water used for mixing and curing the tested samples according to the Egyptian Code of Practice E.C.P. 203/2007 [22].

Table 1: Physical properties of the sand used.

\begin{tabular}{|lc|c|}
\hline \multicolumn{1}{|c|}{ Property } & Value \\
\hline Specific gravity & $\left(\mathrm{t} / \mathrm{m}^{3}\right)$ & 2.71 \\
\hline Volumetric weight & $\left(\mathrm{t} / \mathrm{m}^{3}\right)$ & 1.62 \\
\hline Voids ratio & $(\%)$ & $42.1 \%$ \\
\hline Percent of clay, silt and dust & (by weight) & $0.41 \%$ \\
\hline
\end{tabular}

Table 2: Grading of the sand used.

\begin{tabular}{|c|c|c|c|c|}
\hline Sieve size (mm) & $\mathbf{0 . 6} \mathbf{~ m m}$ & $\mathbf{0 . 3} \mathbf{~ m m}$ & $\mathbf{0 . 1 5} \mathbf{~ m m}$ & $\mathbf{0 . 0 7 4} \mathbf{~ m m}$ \\
\hline Sieve No. & No. 30 & No. 52 & No. 100 & No. 200 \\
\hline \% Passing & 100 & 86 & 52 & 0.7 \\
\hline
\end{tabular}

Silica fume used is a waste by-product of silicon and silicon alloys industry consisting mainly of noncombustible amorphous silica $\left(\mathrm{SiO}_{2}\right)$ particles. It was produced by Egyptian Ferro Alloys Corporation (EFACO). The chemical components analysis is shown in Table (3) and the main properties are shown in Table (4). The silica fume used was met the main requirements of ASTM C 1240.

Table 3: The chemical components analysis result of silica fume used.

\begin{tabular}{|c|c|c|c|c|c|c|c|c|}
\hline $\begin{array}{c}\text { Chemical } \\
\text { Composition }\end{array}$ & $\mathrm{SiO}_{2}$ & $\mathrm{Al}_{2} \mathbf{O}_{3}$ & $\mathbf{F e}_{2} \mathbf{O}_{3}$ & $\mathbf{C a O}$ & $\mathbf{M g O}$ & $\mathbf{S O}_{3}$ & $\mathbf{K}_{2} \mathbf{O}$ & L.O.I. \\
\hline Average (\%) & 95.93 & 0.52 & 0.05 & 0.2 & 0.18 & 0.1 & 0.4 & 2.9 \\
\hline
\end{tabular}

Table 4: Physical properties of the silica fume used.

\begin{tabular}{|lc|c|}
\hline \multicolumn{1}{|c|}{ Property } & Value \\
\hline Specific gravity & $\left(\mathrm{t} / \mathrm{m}^{3}\right)$ & 2.20 \\
\hline Bulk density [uncompacted unit weight] & $\left(\mathrm{t} / \mathrm{m}^{3}\right)$ & 0.25 \\
\hline Fineness & $\left(\mathrm{m}^{2} / \mathrm{gm}\right)$ & 23.42 \\
\hline
\end{tabular}

Super-plasticizer as high-range water-reducing (HRWR) admixture is used to increasing the workability of concrete without additional amount of water. In this study omit a naphthalene sulphonate group based super-plasticizer (S.P.), supplied by Chemicals for Modern Buildings (CMB) 
Company, and under the brand name of Addicrete BVF was used. The main properties are shown in Table (5). The used super-plasticizer complies with ASTM C494-Type F [23] and ESS 1899-1 [24].

Table 5: Technical information of Addicrete BVF (As Provided by Manufacturer).

\begin{tabular}{|c|c|c|c|c|c|}
\hline Base & Appearance & Density & $\begin{array}{c}\text { Chloride } \\
\text { content }\end{array}$ & $\begin{array}{c}\text { Air } \\
\text { entrainment }\end{array}$ & Compatibility \\
\hline $\begin{array}{c}\text { Naphthaline } \\
\text { sulphonate }\end{array}$ & Brown liquid. & $\begin{array}{c}1.18 \pm 0.01 \\
\mathrm{~kg} / \mathrm{litre}\end{array}$ & $\mathrm{Nil}$ & $\mathrm{Nil}$ & $\begin{array}{c}\text { All types of } \\
\text { Portland cement }\end{array}$ \\
\hline
\end{tabular}

The steel fibers used in this investigation are clean of rust or oil of straight steel wire fibers. The length of fibers is $13 \mathrm{~mm}$ and its diameter $0.8 \pm 0.02 \mathrm{~mm}$ with aspect ratio (l/d) of 16.25 . The properties of the steel fibers used are shown in Table (6).

The steel rebars used in this experimental work are two types. The first was the normal strength mild steel rebars (St.37) which used for the passive reinforcement and shear reinforcement (stirrups) with rounded plain bars with $8 \mathrm{~mm}$ diameter. The second type was high tensile steel rebars (St.52) which used for the main reinforcement with $10 \mathrm{~mm}$ diameter. Yield stress, ultimate strength and modulus of elasticity of both types were given in Table (6).

Table 6: Test results of steel fibers and reinforcement used (based on laboratory tests).

\begin{tabular}{|c|c|c|c|c|}
\hline Steel Type & $\begin{array}{c}\text { Yield Stress } \\
(\mathbf{M P a})\end{array}$ & $\begin{array}{c}\text { Tensile Strength } \\
\mathbf{( M P a )}\end{array}$ & $\begin{array}{c}\text { Elongation } \\
(\mathbf{\%})\end{array}$ & $\begin{array}{c}\text { Modulus of } \\
\text { Elasticity } \\
(\mathbf{G P a})\end{array}$ \\
\hline Steel Fibers & 355 & 525 & 14 & 200 \\
\hline Mild steel & 295 & 399 & 22.2 & 202 \\
\hline $\begin{array}{c}\text { High Tensile } \\
\text { Steel }\end{array}$ & 368 & 531 & 13.2 & 200 \\
\hline
\end{tabular}

\subsection{Mixtures Proportions}

The mixture ratios were based on guidelines and specifications given in several different approaches presented in literature. Mixture proportions used in this investigation are chosen based on (Meleka et al., 2013) [25] and summarized in Table (7). The first group is coded by (C) and casts without steel fiber content, while the second group is coded by (CS) which casts using steel fibers.

Cement content that was chosen in this research as 700,750 and $800 \mathrm{~kg} / \mathrm{m}^{3}$ to be within the usual range $\left(600-1000 \mathrm{~kg} / \mathrm{m}^{3}\right)$ that was adopted by many researchers as shown previously in the literature. Sand content was the same for all the mixtures in this research. It was chosen to be $1230 \mathrm{~kg} / \mathrm{m}^{3}$ [26]. Many researchers (Reeves, 2004; Lee et al., 2006, 2007) [17, 27, 28] choose the fine sand content to be $1020 \mathrm{~kg} / \mathrm{m}^{3}$ but they use quartz powder of $210 \mathrm{~kg} / \mathrm{m}^{3}$ content. In this research, El-Arish sand is used with its grading without adding any quartz powder to make the RPC beams are more economical so that, $1230 \mathrm{~kg} / \mathrm{m}^{3}$ of sand was chosen. The water/cement ratio was taken between 0.17 and 0.19 for fibered reactive concrete and between 0.15 and 0.17 for plain reactive concrete according to (Richard and Cheyrezy, 1995; Cheyrezy et al., 1995) [4, 5]. In this research the w/c ratio was chosen to be 0.18 for all mixtures.

Table 7: Concrete mixes used and their main mechanical properties.

\begin{tabular}{|c|c|c|c|c|c|c|c|c|c|c|}
\hline \multirow{2}{*}{ Mix } & \multirow{2}{*}{$\begin{array}{c}\text { Cement } \\
\left(\mathrm{kg} / \mathrm{m}^{3}\right)\end{array}$} & \multirow{2}{*}{$\begin{array}{l}\text { Water } \\
\left(\mathrm{kg} / \mathrm{m}^{3}\right)\end{array}$} & \multirow{2}{*}{$\begin{array}{l}\text { Sand } \\
\left(\mathrm{kg} / \mathrm{m}^{3}\right)\end{array}$} & \multirow{2}{*}{$\begin{array}{l}\text { Fibers } \\
\left(\mathrm{kg} / \mathrm{m}^{3}\right)\end{array}$} & \multirow{2}{*}{$\begin{array}{l}\text { Silica } \\
\text { Fume } \\
\left(\mathrm{kg} / \mathrm{m}^{3}\right)\end{array}$} & \multirow{2}{*}{$\begin{array}{c}\text { Super- } \\
\text { plasticiz } \\
\text { er } \\
\left(\mathrm{kg} / \mathrm{m}^{3}\right)\end{array}$} & \multicolumn{2}{|c|}{$\begin{array}{l}\text { Compressive } \\
\text { Strength }\end{array}$} & \multirow{2}{*}{$\begin{array}{c}\begin{array}{c}\text { Modulus } \\
\text { of } \\
\text { Elasticity }\end{array} \\
\mathrm{E}_{28} \\
(G P a)\end{array}$} & \multirow{2}{*}{$\begin{array}{c}\begin{array}{c}\text { Flexural } \\
\text { Strength }\end{array} \\
\begin{array}{c}\mathrm{F}_{\mathrm{t}} \\
(M P a)\end{array}\end{array}$} \\
\hline & & & & & & & $\begin{array}{c}\mathrm{F}_{\mathrm{cu} 7} \\
(\mathrm{MPa})\end{array}$ & $\begin{array}{c}\mathrm{F}_{\text {cu } 28} \\
(\mathrm{MPa})\end{array}$ & & \\
\hline NSC & 350 & 157.5 & $\begin{array}{c}\text { Sand }=658 \\
\text { gravel=1237 }\end{array}$ & \multirow{2}{*}{$\begin{array}{c}\text { without } \\
\text { steel }\end{array}$} & -- & -- & 23 & 28.5 & 21 & 2.85 \\
\hline B700 & 700 & 126 & 1230 & & 210 & 70 & 111.5 & 114 & 31.58 & 9.49 \\
\hline
\end{tabular}




\begin{tabular}{|c|c|c|c|c|c|c|c|c|c|c|}
\hline B750 & 750 & 135 & & \multirow[t]{2}{*}{ fibers } & 225 & 75 & 123.5 & 127 & 35.44 & 13.31 \\
\hline B800 & 800 & 144 & & & 240 & 80 & 149.5 & 150.5 & 40.99 & 14.73 \\
\hline B700F & 700 & 126 & \multirow{3}{*}{1230} & \multirow{3}{*}{$\begin{array}{l}\text { with } \\
\text { steel } \\
\text { fibers } \\
40 \mathrm{~kg}\end{array}$} & 210 & 70 & 116 & 120 & 35.45 & 24.51 \\
\hline B750F & 750 & 135 & & & 225 & 75 & 130.5 & 133 & 40.95 & 27.61 \\
\hline B800F & 800 & 144 & & & 240 & 80 & 153.5 & 154.5 & 45.10 & 30.26 \\
\hline
\end{tabular}

To investigate the effect of using silica fume on the behavior of the reactive concrete, three contents of silica fume were used as a percentage of the mixture cement content. The used percentages were $0 \%, 15 \%$ and $30 \%$ of the cement content. The used super-plasticizer is considered as $10 \%$ of cement content [26].

Steel fibers are among the main parameters that divide the mixtures into two groups. The first group "MS" was the reactive fiber reinforced concrete with $40 \mathrm{~kg} / \mathrm{m}^{3}$ steel fiber content which was chosen in accordance to (Reeves, 2004) [17] (reported that the steel fiber content was ranging between $40 \mathrm{~kg} / \mathrm{m}^{3}$ and $160 \mathrm{~kg} / \mathrm{m}^{3}$ ). The lower limit of $40 \mathrm{~kg} / \mathrm{m}^{3}$ was chosen for more cost saving. The second group "M" was the plain reactive concrete with no fiber content.

\subsection{Mixing Casting and Curing Processes}

The mixing process was performed using a ring concrete mixer of 15 liters capacity as shown in Fig. (1). The compaction process were performed by concrete vibrator which was slowly insert and was not allow being rest on or touching the bottom or sides of the mould. After vibrating rod strokes were distributed uniformly over the cross section of the mould to ensure the best compaction especially for the final layer.

Specimens were demoulded 24 hours after casting and water cured at about $75^{\circ} \mathrm{C}$ for 3 days then in $25^{\circ} \mathrm{C}$ for another 3 days after those specimens was gotten out from the water to a dry place till the age of testing. For maintaining uniform curing all the specimens were cured in the same curing tanks.

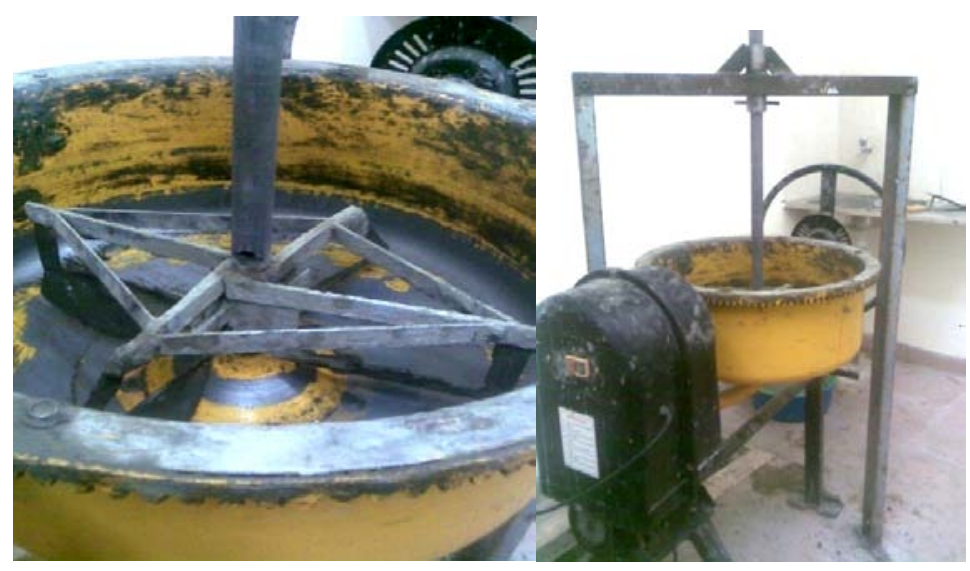

Figure 1. The concrete mixer used.

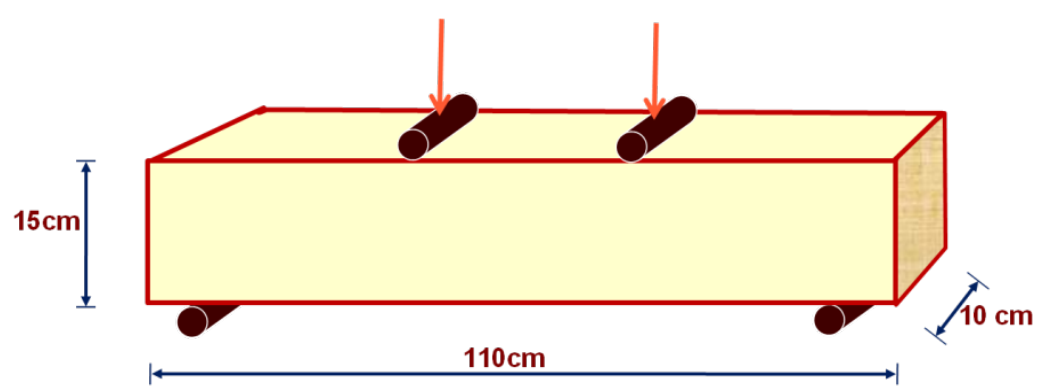

Figure 2. Isometric view for the beam cross section.

\subsection{Concrete Samples}


Concrete samples are cast to evaluate the main mechanical properties of RPC mixes used. Standard cubes of dimensions $10 \times 10 \times 10 \mathrm{~cm}$ for measuring the compressive strength, cylinders of $10 \mathrm{~cm}$ diameter and $20 \mathrm{~cm}$ height for measuring the indirect tensile strength and the modulus of elasticity and their results are shown in Table (7).

Twenty four simply support reinforced RPC beams of dimensions $10 \times 15 \times 110 \mathrm{~cm}$ are cast then, divided in to six groups.

The groups and the reinforcing details of beams are shown in Table (8). Each group contains four beams reinforced by using two different systems. The first system was carried out by placing shear and bending steel reinforcement abbreviated as (S-B) and the second system was carried out by placing bending steel reinforcement only abbreviated as (B) as shown in Table (8).

Table 8: Samples codes and reinforcing details of the tested beams.

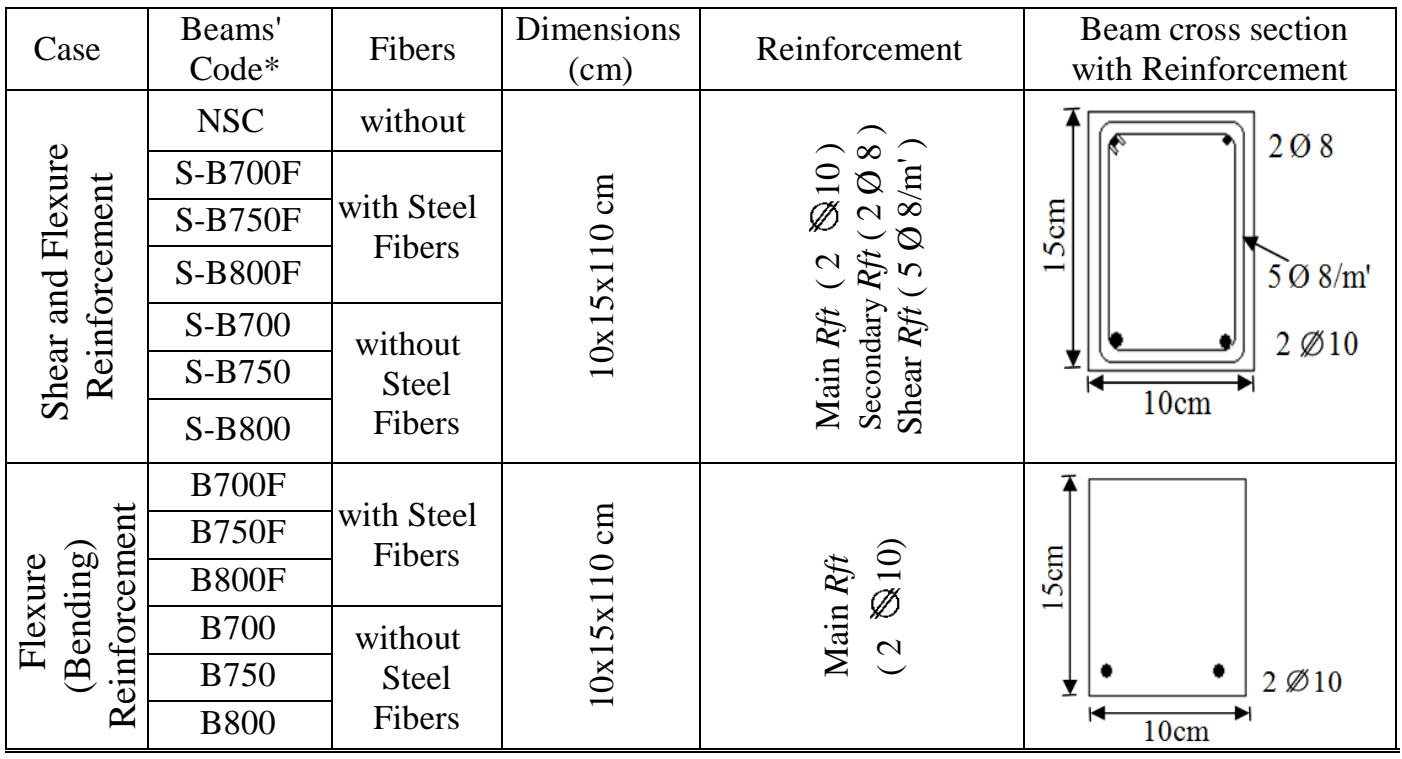

*The beams' code is the same as mixes but the shear reinforced beams are referee by $S$

\subsection{Testing Procedures and Equipments}

All tests in this research were carried out to investigate the main properties of reinforced RPC beams as reported in this section.

Compression Test: was carried out to determine the compressive strength of specimens of concrete cubes. A $2000 \mathrm{KN}$ capacity compression testing machine was used.

Modulus of Elasticity Test: The modulus of elasticity of cylindrical specimens was determined. Stresses and corresponding strains were evaluated and average values were calculated. A $2000 \mathrm{KN}$ capacity compression testing machine was used to apply a compressive axial load and Compress meter (dial gauge with accuracy $0.01 \mathrm{~mm}$ and a maximum capacity of $10 \mathrm{~mm}$ ) was used.

Tension Test: Indirect tension test (splitting method) was performed to determine the tensile strength of concrete mixes using cylindrical specimens of RPC. A $2000 \mathrm{KN}$ capacity compression testing machine was used.

Prism Flexural Test: This test method evaluates the flexural strength of the tested prism specimens using a flexure testing machine of $150 \mathrm{KN}$ capacities.

Beam Flexural Test: It is performed using four-point load system. Figure (2) shows the beam dimensions. A steel frame with two movable I-beam girders to work as a support for beams was used. The load was applied by a hydraulic cylinder double acting with 150 ton capacity and $150 \mathrm{~mm}$ maximum Stroke which was connected to a hydraulic electric oil pump for feeding the hydraulic jack. 
The applied load was measured by a load cell of 225 ton capacity. An LVDT for measuring displacements up to at least $100 \mathrm{~mm}$ was placed under each beam at the center of its span to measure deflections were used for deflection measurements within the region of pure bending between the two load points. The load cell and the LVDT were connected to a data logger that shows a continuous record of the applied load and the corresponding deflection at mid span.

The behaviors of the materials used as well as beam behavior are estimated from the results recorded during testing of RPC samples. The results of beam samples in terms of initial cracking load, deflection at each load increment at the center of the lower surface of each beam, ultimate load, and crack propagation are recorded at each stage of loading.

\section{FINITE ELEMENT ANALYSIS}

Several researchers $[20,29]$ have studied the nonlinear analysis of beams. A nonlinear computer program based on the finite element techniques applied to study the behavior of reinforced RPC beams. Geometric and material nonlinearities have been considered. The material nonlinearities are taken into consideration. The nonlinearities include the stress-strain relationship for concrete and steel reinforcement, concrete cracking and tension stiffening effects. The efficiency and accuracy of the computer program are verified by comparing its results with the experimental results.

A nonlinear finite element FE computer program performed by (Meleka, 1995) [20] is used. Longitudinal direction is consists of 8 elements as shown in Fig. (3).

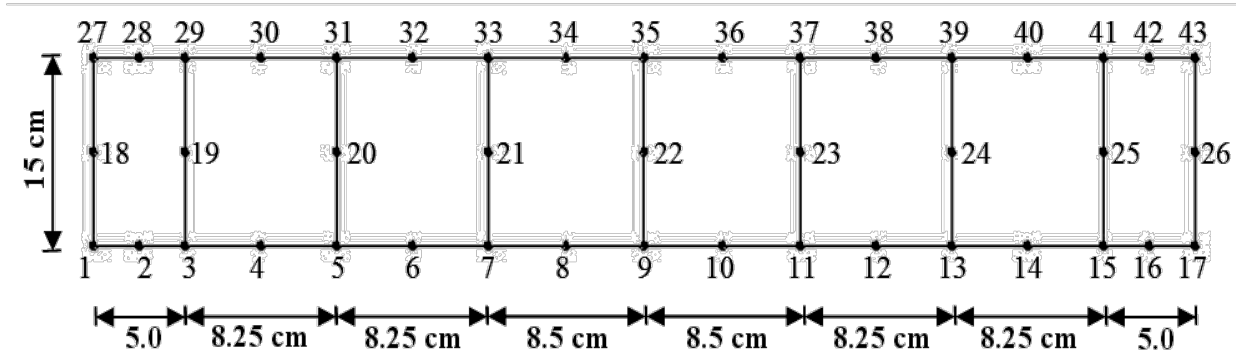

Figure 3. Finite element mesh in XY plan for beam model.

For support (A), node "3" is restrained only in $\mathrm{X}$ and $\mathrm{Z}$ directions while free in $\mathrm{Y}$ direction also the rotation about $\mathrm{Y}$ axis is permitted. At support (B), node "15" is restrained only in $\mathrm{X}$ and a $\mathrm{Z}$ direction while free in $\mathrm{Y}$ direction also the rotation about $\mathrm{Y}$ axis is permitted.

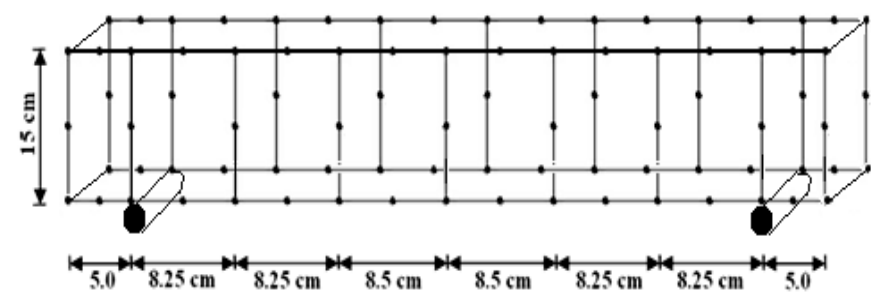

Figure 4. Finite element model for beam model.

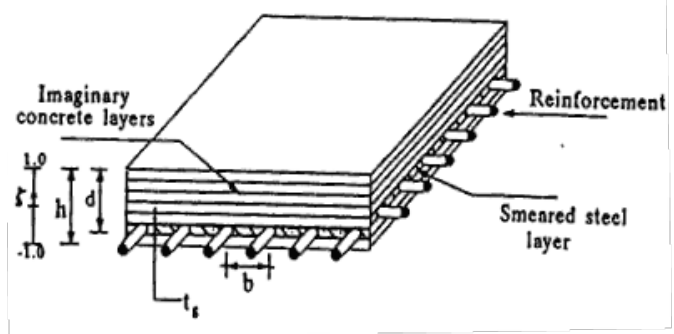

Figure 5. Modeling of reinforced concrete layered element.

The beams are analyzed by the computer program based on the nonlinear finite element analyses which based on the nonlinear finite element method. The dimension of this tested beam is $10 \times 15 \times 110 \mathrm{~cm}$ is simply supported. The reinforcements of different reinforced concrete beam samples are considered as illustrated at Table (8). A four-point load test is used. The load increment is applied 
by $200 \mathrm{~kg}$ up to failure to simulate the experimental program. The material properties and dimensions are:

1. Height of the beam $=15 \mathrm{~cm}$

2. Width of the beam $=10 \mathrm{~cm}$

3. Compressive strength values " $F_{\text {cu } 28}$ " were considered as given at Table (7) for each beam.

4. Modulus of rupture " $f_{t}$ " was considered for each beam as given at Table (7).

5. Yield strength of steel $\mathrm{f}_{\mathrm{y}}=360 \mathrm{MPa}$

6. Young's modulus of steel $\mathrm{E}_{\mathrm{s}}=2.1 \times 10^{5} \mathrm{MPa}$

7. Young's modulus of concrete $\mathrm{E}_{\mathrm{c}}=2 \times 10^{4} \mathrm{MPa}$

8. Poisson's ratio $\mathrm{v}=0.2$

9. Concrete cover $\mathrm{c}=1 \mathrm{~cm}$

Two normal strength concrete NSC beams of the same dimension and reinforcement as the case of shear and flexure (Bending) reinforcement in Table (7) were cast to investigate the efficiency of the nonlinear finite element program when dealing with NSC and compare that to the results obtained when dealing with the tested reactive concrete beams. The boundary conditions are the same as given before. The used NSC properties were as follow:

1. Compressive strength of concrete

$$
\begin{gathered}
\mathrm{F}_{\text {cu } 28}=28.5 \mathrm{MPa} \\
\mathrm{f}_{\mathrm{t}}=2.85 \mathrm{MPa} \\
\mathrm{E}_{\mathrm{s}}=21000 \mathrm{MPa} \\
v=0.2
\end{gathered}
$$

2. Modulus of rupture of concrete

3. Young's modulus of concrete

4. Poisson's ratio

The used material properties for the cast beams were indicated from the executed experimental program and that were explained and discussed in section 3. The compressive strength used in the finite element analysis was:

$$
\mathrm{f}_{\mathrm{c}}{ }^{\prime}=0.8 \mathrm{f}_{\mathrm{cu}}
$$

where $\mathrm{f}_{\mathrm{cu}}$ was the 28 days compressive strength of the reactive concrete type that used in beam casting. The tensile strength used in the finite element analysis was:

$$
\mathrm{f}_{\mathrm{t}}{ }^{\prime}=0.8 \mathrm{f}_{\mathrm{t}}
$$

where $f_{t}$ was the 28 days tensile strength of the reactive concrete type that used in beam casting indicated from indirect tension test results.

The modulus of elasticity $\left(E_{c}\right)$ used in the finite element analysis was obtained from the 28 days modulus of elasticity of the reactive concrete type that used in beam casting. Poisson's ratio (v) was chosen to be 0.2 for all the tested beams according to JSCE, (2006) [6].

Modeling beam in the nonlinear finite element computer program was by divided the into 8 element which translated into 43 nodes in the XY plan and 8 layers of reactive concrete in $\mathrm{Z}$ direction while the steel reinforcement was modeled according to the tested beam type to simulate the reinforcement in the real beam. Figures (3) and (4) show the XY plan for modeled beams.

\section{TEST RESULTS}

Initial cracking loads and failure loads for each beam are shown in Fig. (6). Load-deflection curves at lower midpoint of different beams are shown in Figs. (7) to (12).

\subsection{Cracking Loads}

The first crack load $\left(\mathrm{P}_{\mathrm{cr}}\right.$ in Fig. (6)) was determined from the main curve in the load deflection curve at initial stages of loading. The cracking loads for beams cast using different cement contents, with and without steel fibres and having shear and bending steel reinforcement was shown in Fig. (6). The increasing of the cracking load with respect to the cracking load of beam SB700F was $8.8 \%$ and $18.0 \%$ for beams SB750F and SB800F respectively. The cracking load for beams cast using different cement content without fiber reinforcement and having shear and bending steel reinforcement indicated that the 
increasing is $17.6 \%$ and $28.1 \%$ for beams SB750 and SB800 respectively compared to SB700.

For beams cast using only bending steel reinforcement, the cracking load increased with respect to the cracking load of beam B700F by about $9.7 \%$ and $16.4 \%$ for beams $\mathrm{B} 750 \mathrm{~F}$ and B800F respectively. For beams cast using different cement content without fiber reinforcement and having only bending steel reinforcement, the increasing of the cracking load with respect to the cracking load of beam B700 was $12.6 \%$ and $25.7 \%$ for beams B750 and B800.

There was a positive effect on the cracking load of reactive concrete beams due to increasing of the cement content regardless the steel fibres reinforcement and the type of steel reinforcement as shown in Fig. (6). Using steel fibres enhances the performance of RPC beams in agree with (JSCE, 2006; Al-Hassani et al., 2014; Habel et al., 2006; Orgass et al., 2004 ) [6, 9, 10, 13].

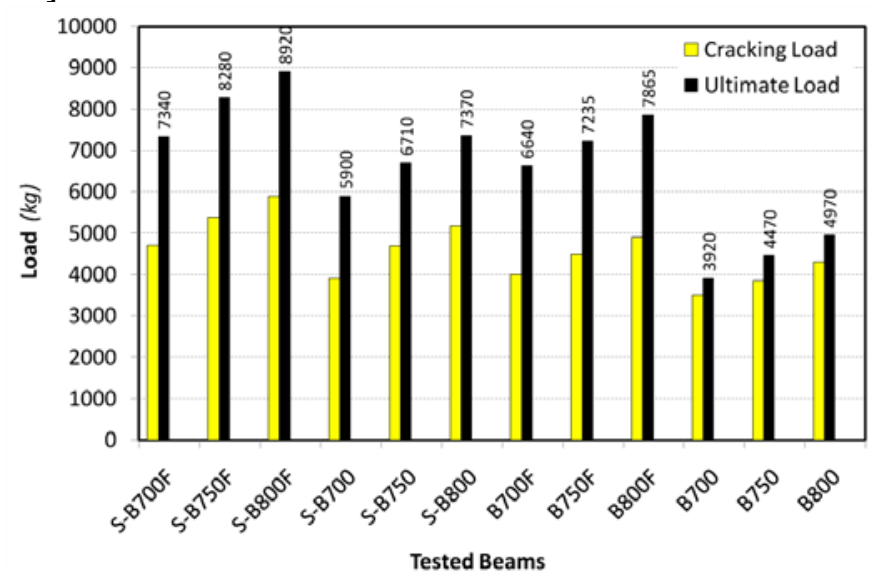

Figure 6. Initial cracking loads and ultimate loads for all tested beam samples.

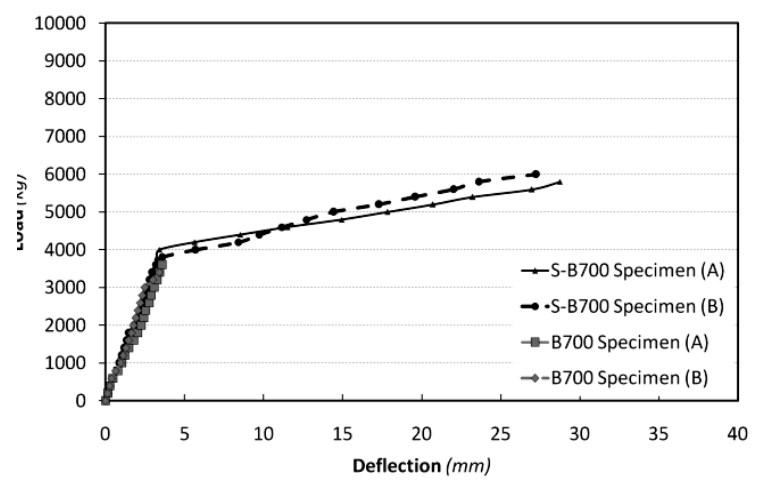

Figure 7. Deflection values of S-B700 \& B700 $\left(700 \mathrm{~kg} / \mathrm{m}^{3}\right.$ cement content without steel fibers).

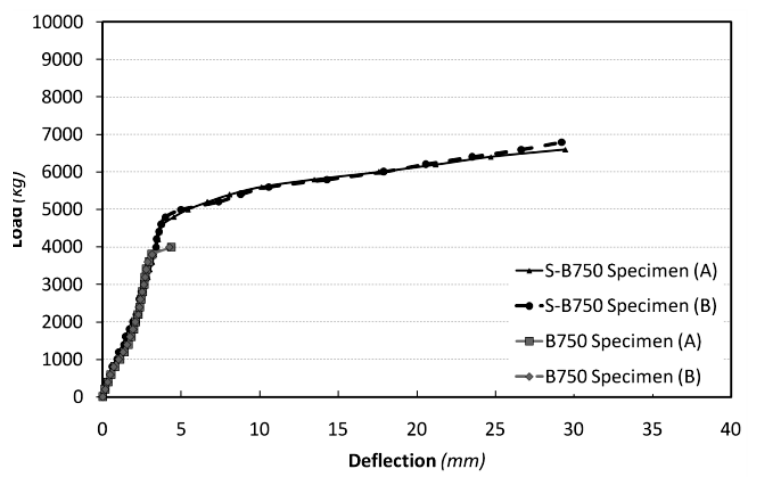

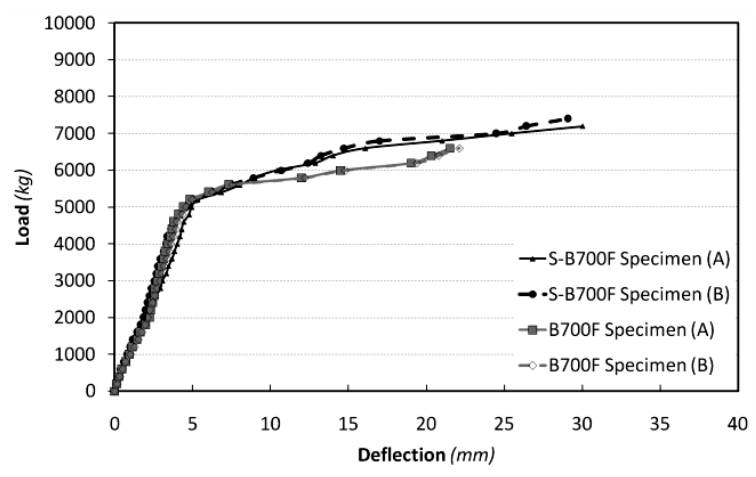

Figure 8. Deflection values of S-B700F \& B700F $\left(700 \mathrm{~kg} / \mathrm{m}^{3}\right.$ cement content with steel fibers).

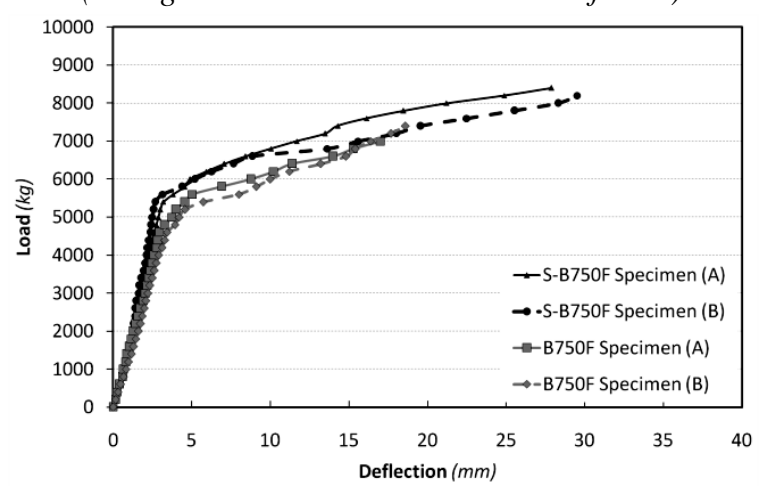


Figure 9. Deflection values of S-B750 \& B750 $\left(750 \mathrm{~kg} / \mathrm{m}^{3}\right.$ cement content without steel fibers).

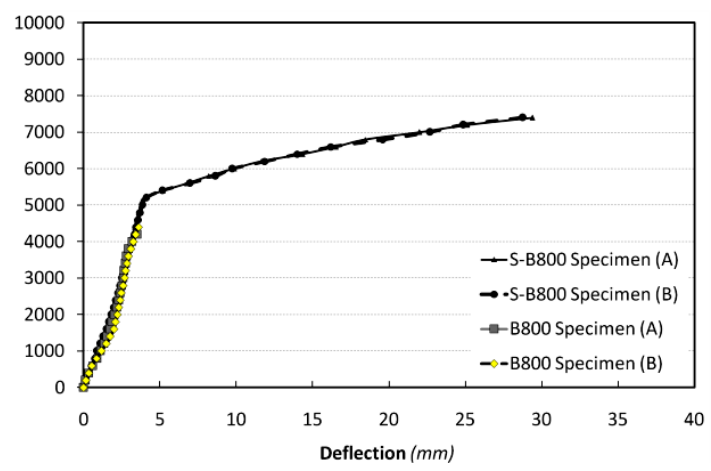

Figure 11. Deflection values of S-B800 \& B800 $\left(800 \mathrm{~kg} / \mathrm{m}^{3}\right.$ cement content without steel fibers).
Figure 10. Deflection values of S-B750F \& B750F (750kg/m $\mathrm{m}^{3}$ cement content with steel fibers).

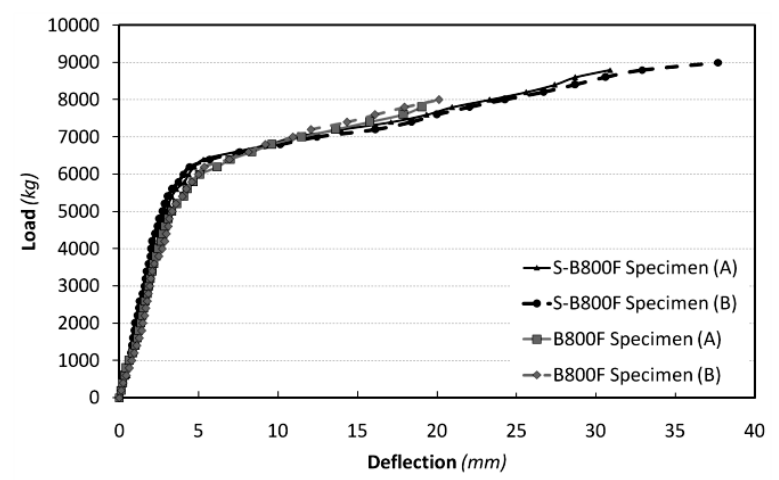

Figure 12. Deflection values of S-B800F \& B800F $\left(800 \mathrm{~kg} / \mathrm{m}^{3}\right.$ cement content with steel fibers).

\subsection{Load Capacity of Beams}

The four major stages are observed on load deflection curves for all the beams as shown in Figs. (7) to (13). The load corresponding to stage 1, 2, 3, 4, on load deflection curves are noticed as first cracking load $\left(\mathrm{P}_{\mathrm{cr}}\right)$, Yield point load $\left(\mathrm{P}_{\mathrm{y}}\right)$, maximum load $\left(\mathrm{P}_{\mathrm{m}}\right)$, and ultimate load $\left(\mathrm{P}_{\mathrm{u}}\right)$ respectively.

\subsection{Deflection of Tested Beams}

Typical load-deflection curves for reinforced concrete beams of two types, PRC and NSC reinforced beams are recorded. Figures (7) to (12) illustrate the typical load-deflection characteristics of all types of beams. Comparison shows clearly that the deflection of RPC beams at all load stages is less than that of NSC RC beams at the same load.

From these observations it is evident that RPC beams showed better stiffness characteristics than NSC reinforced concrete beams at Fig. (13). Those results are in agree with (Gao et al., 2005; Warnock, 2005; Reeves, 2004; Yang et al., 2010) [14, 15, 17, 18].

\subsection{Failure Loads for Beams}

The ultimate load for beams cast using different cement content reinforced with steel fibres and having shear and bending steel reinforcement was shown in Fig. (6). The average cube strength (at Table 7) of control specimens were used to determine the ultimate load of these beams and the theoretical load was compared with average ultimate load of RC beams tested under static loading. It was shown that the increasing of the ultimate load with respect to the ultimate load of beam SB700F was $12.9 \%$ and $21.6 \%$ for beams SB750F and SB800F.

For beams cast using different cement content without fiber reinforcement and having shear and bending steel reinforcement, the increasing of the ultimate loads for beams SB750 and SB800 was $13.8 \%$ and $25.0 \%$ compared to beam SB700. Increasing cement content and using steel fibres improve the behaviour of RPC beams satisfying the previous researchers [14, 15, 17, 18].

\subsection{Crack Patterns}

The crack patterns are recorded, illustrated and photographed at each load increment. The number of cracks decreased in all RPC beams compared to NSC beams at the same load in agreement with previous researches $[14,15,17,18]$. This result shows that, there is a brittle failure behavior and therefore a limited post-crack behavior, so the elements fail explosively with a lower post-cracking ductile behavior and were able to reduce cracking which satisfies (Orgass, 2004; Yang et al., 2010) $[13,18]$. The improvement in the cracking behavior depends on the cement content and fiber content. 


\subsection{Comparison between Finite Element Analysis and Experimental Results}

Reinforced RPC beams that have the designation and properties that illustrated in Table (7) were modeled using a finite element program that was developed by Meleka [20] and its modifications by Meleka et al. [29, 30]. The load deflection behavior of the 13 different tested beams types was analyzed by the computer program based on the nonlinear finite element analyses. Deflection was determined at mid span at the centre of the bottom face of the beam. Figures (14) to (25) show the load deflection curves of the beams for both the experimental and numerical data. There was easy to model the two types of steel reinforcement used in this research even bending and shear reinforcement or bending reinforcement only using the nonlinear FE program of Meleka [29]. A linear computer program SAP2000 (version 14) which based on the linear finite element method was used. The steel reinforcement in bending only could be modeled but when dealing with shear reinforcement SAP2000 program could not be modeled. The results of linear computer program SAP2000 was shown in Figs $(14,15,18,19,22,23)$.

Figure (13) shows the load deflection curves for the two experimentally cast beams and the results obtained from the nonlinear finite element program. From the figure it could be indicated that the used nonlinear finite element program results was identical to the experimental results and that was a prove to the great efficiency of the used program in analyzing NSC beams.

Figures (13) to (25) show the load deflection curves for the 13 different tested beams types. The results of the 2 beams tested experimentally and the results indicated from the nonlinear finite element program were shown in the previous. The SAP2000 program results were shown in Figures for beams that have steel bending reinforcement only.

It is noticed that from Figures (13) to (25) that the results of the nonlinear analysis approach the experimental results and that was a good prove to the effectiveness of using this nonlinear finite element program in analyzing and predicting the behavior of the reactive concrete beams. In general, the load deflection curve for the beam from the numerical results has excellent agreement with the experimental data.

It is clear that SAP2000 results were very close to the experimental and the nonlinear finite element program results in the linear phase of the load deflection curve but it were deviated after cracking load in the nonlinear phase of the load deflection curve.

Two normal strength concrete beams of the same dimension and reinforcement as the case of shear and flexure (Bending) reinforcement as shown in Table (8) were cast to investigate the efficiency of the nonlinear finite element program when dealing with normal strength concrete and compare that to the results obtained when dealing with the tested reactive concrete beams.

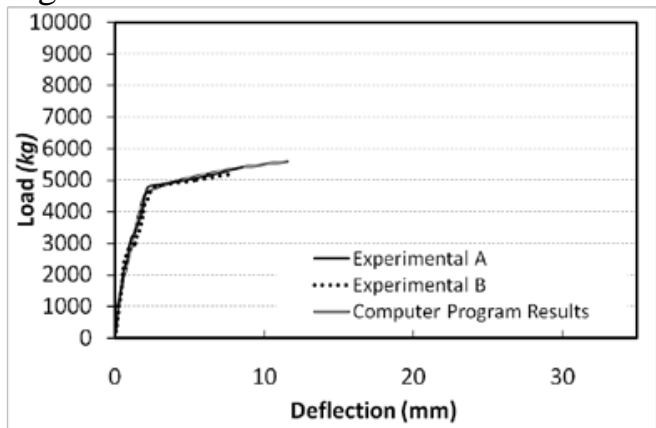

Figure 13. Comparison between deflection values of normal strength beam experimentally and by using FE model. 


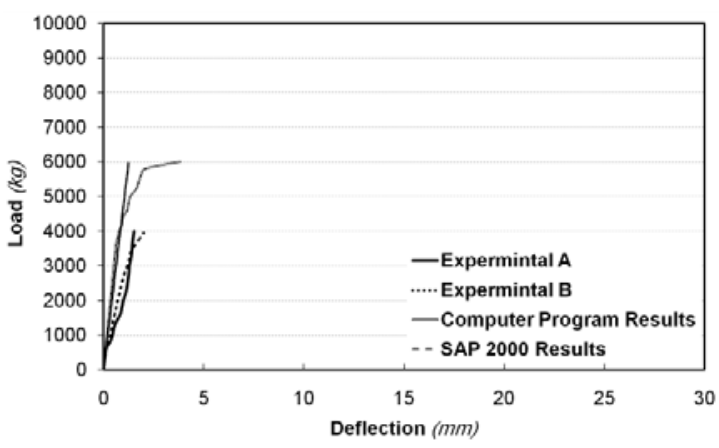

Figure 14. Comparison between deflection values of beam B700 experimentally and by using FE model.

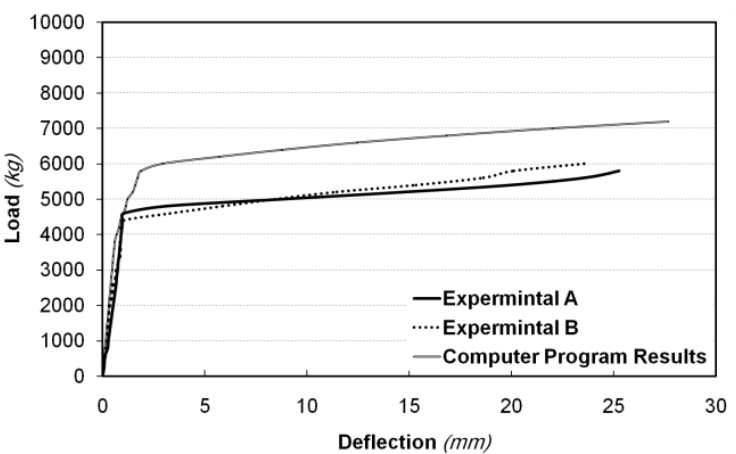

Figure 16. Comparison between deflection values of beam S-B700 experimentally and by using FE model.

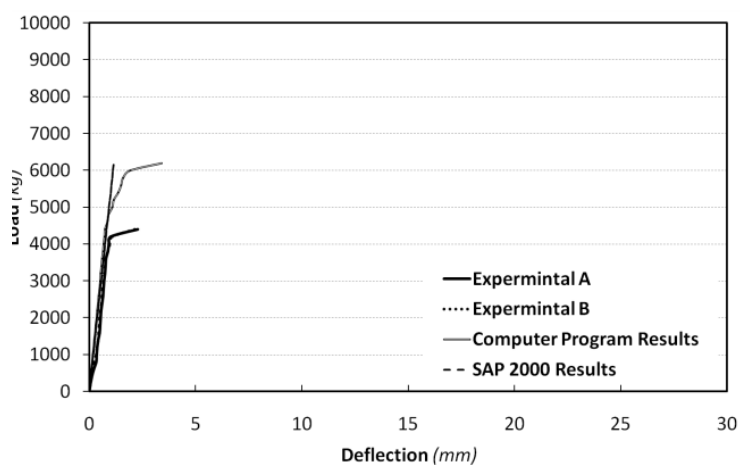

Figure 18. Comparison between deflection values of beam B750 experimentally and by using FE model.

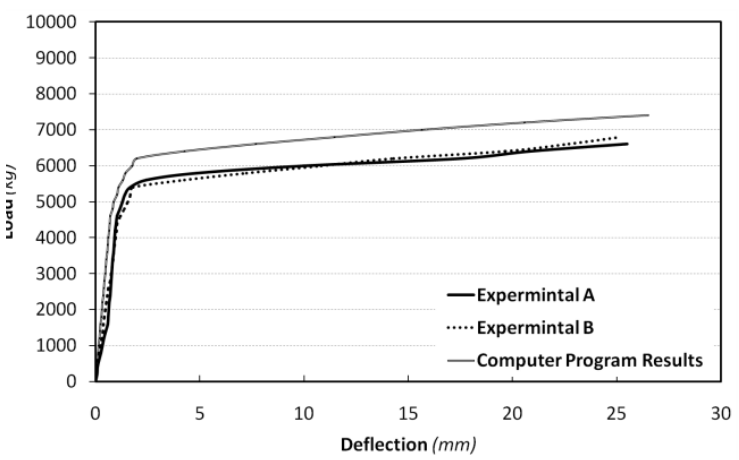

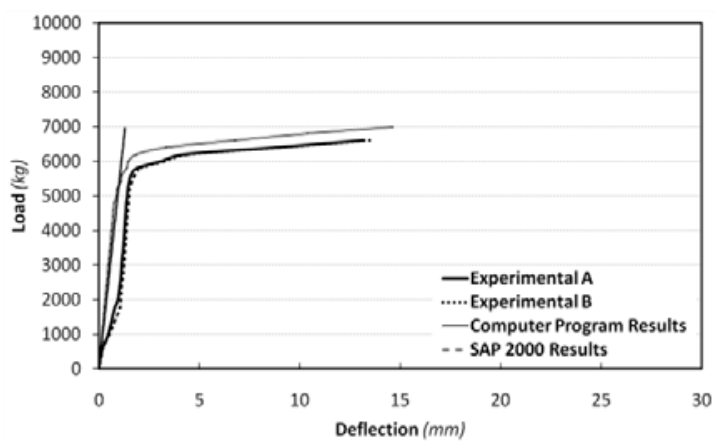

Figure 15. Comparison between deflection values of beam B700F experimentally and by using FE model.

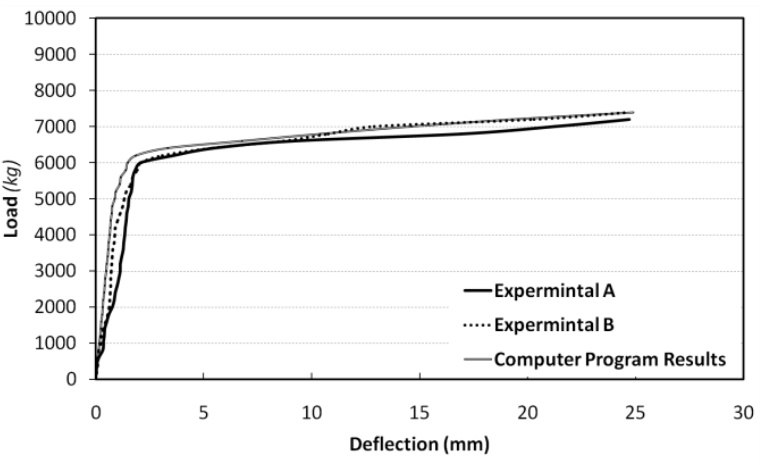

Figure 17. Comparison between deflection values of beam S-B700F experimentally and by using FE model.

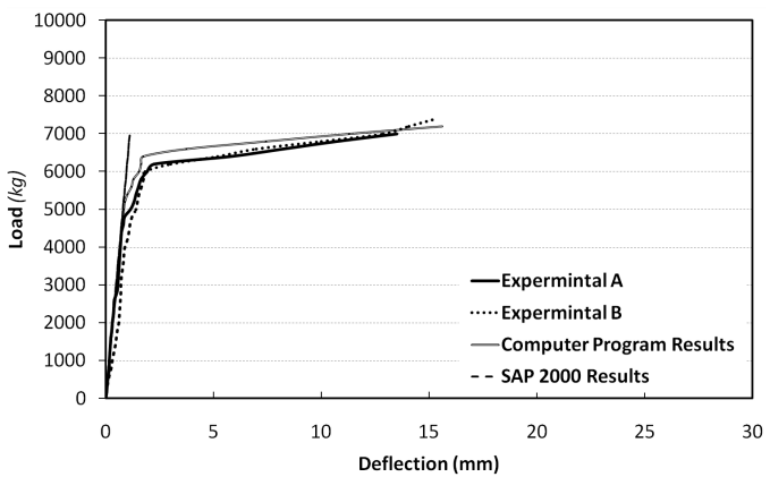

Figure 19. Comparison between deflection values of beam B750F experimentally and by using FE model.

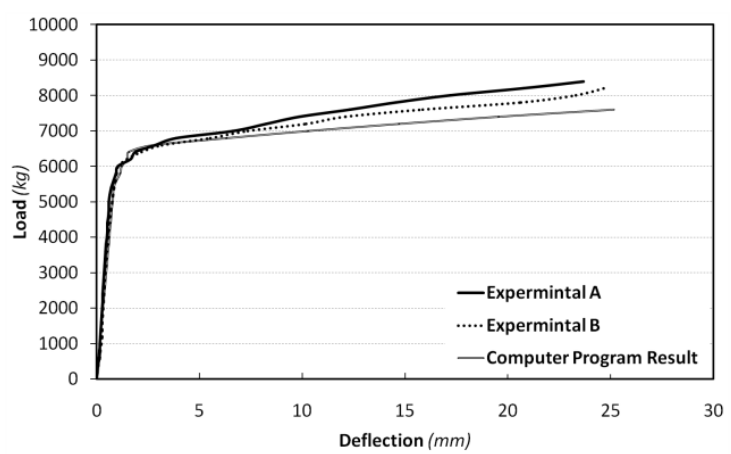


Figure 20. Comparison between deflection values of beam S-B750 experimentally and by using FE model.

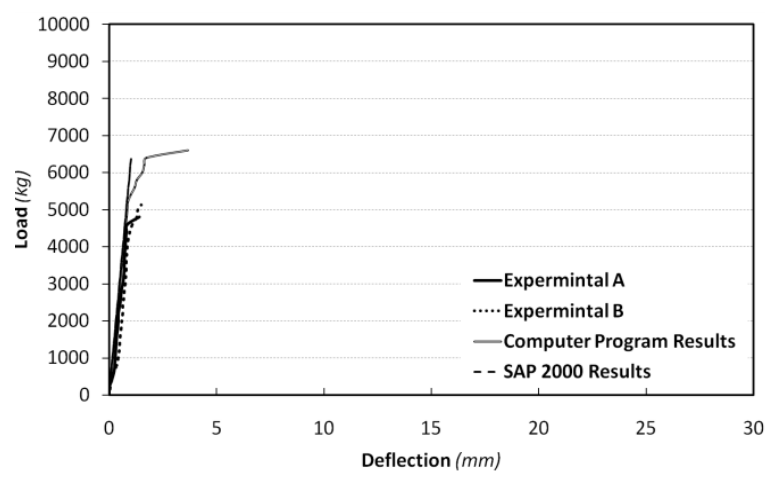

Figure 22. Comparison between deflection values of beam B800 experimentally and by using FE model.

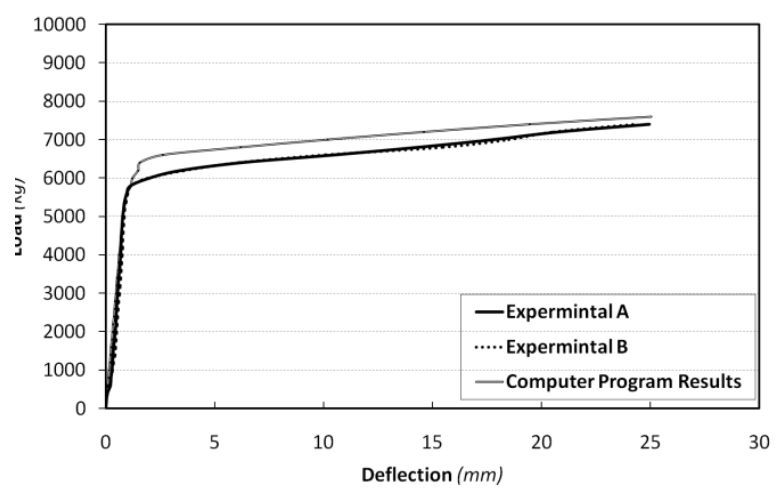

Figure 24. Comparison between deflection values of beam S-B800 experimentally and by using FE model.
Figure 21. Comparison between deflection values of beam S-B750F experimentally and by using FE model.

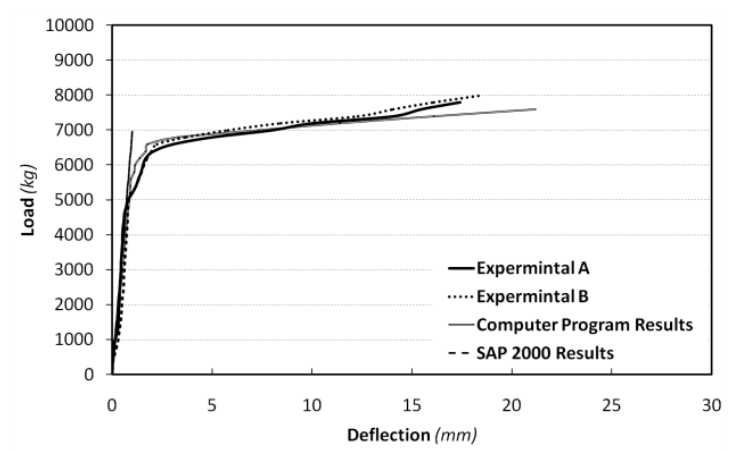

Figure 23. Comparison between deflection values of beam B800F experimentally and by using FE model.

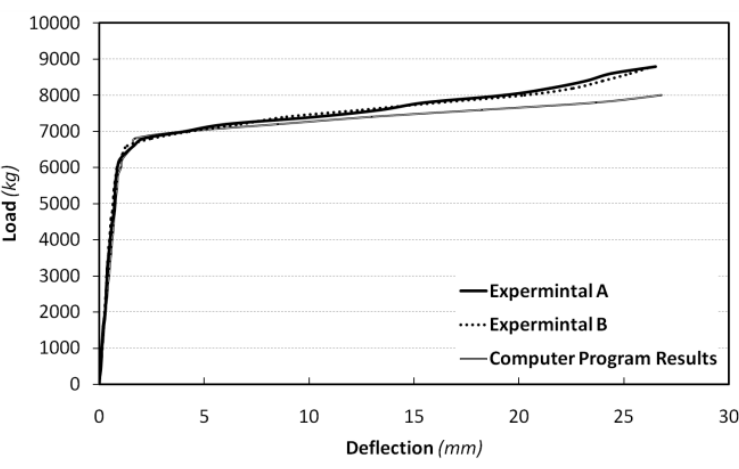

Figure 25. Comparison between deflection values of beam S-B800F experimentally and by using FE model.

\section{CONCLUSIONS}

Based on the available research results, the following main conclusions for the behavior of reinforced RPC beams as follows:

1. The load deflection relationship of the tested beams indicated the great effect of the steel fiber content on the ductility of the reactive concrete beams especially for beams that has only flexure reinforcement.

2. Results showed that there was a positive effect of using shear reinforcement (the shear reinforcing in this research was by stirrups) and it is really important especially in the case of using plain reactive concrete without any steel fibers reinforcement.

3. There is an increasing in the ultimate load of reactive concrete beams with respect to its cracking load which was ranging between $26.0 \%$ to $38.0 \%$ but in case of having only bending steel reinforcement and without steel fibers reinforcement there were nearly no increase in the ultimate load with respect to the cracking load.

4. The used nonlinear finite element computer program results are practically close enough to the experimental results and this program was found to be effective when dealing with reactive concrete beams.

5. The suggested FE model of quadrilateral iso-parametric degenerated element method applied in this research can perform the analysis of RPC beams as well as ultra high strength concrete UHSC efficiently and it is quite accurate in representing the problem. 
Generally, RPC can effectively use as prefabricated concrete beam elements due to its ultra high mechanical properties but it is not recommended to use with elevated temperatures [32].

\section{REFERENCES}

1. Xiaoa, J.; Schneiderb, H.; Donneckeb, C.; and Konigb, G., 2004, "Wedge Splitting Test on Fracture Behaviour of Ultra High Strength Concrete," Construction and Building Materials, Vol. 18, pp. 359-365.

2. Moallem, M.R., 2010, "Flexural Redistribution in Ultra-High Performance Concrete Lab Specimens," M.Sc. Thesis, Russ College of Engineering and Technology, Ohio University, USA.

3. Washer, G.; Fuchs, P.; and Graybeal, B., 2003, "Elastic Properties of Reactive Powder Concrete," International Symposium on Non-Destructive Testing in Civil Engineering (NDT-CE 2003), Germany.

4. Richard, P., and Cheyrezy, M., 1995, "Composition of Reactive Powder Concrete," Cement and Concrete Research, Vol. 5, No.7, pp. 1501-1511.

5. Cheyrezy, M.; Maret, V.; and Frouin, L., 1995, "Micro structural analysis of RPC (Reactive Powder Concrete)," Cement and Concrete Research, Vol. 25, No.7, pp. 1491-1500.

6. JSCE No. 9 , 2006, "Guidelines for Concrete, Recommendation for Design and Construction of Ultra High Strength Fibre Reinforced Concrete Structures (Draft)," Japan Society of Civil Engineers (JSCE), Japan.

7. Shihada, S., and Arafa M., 2010, "Effects of Silica Fume, Ultra Fine and Mixing Sequences on Properties of Ultra High Performance Concrete," Asian Journal of Materials Science Vol. 2, No. 3, pp.137-146.

8. Rashid, M.A., and Mansur, MA., 2009, "Considerations in Producing High Strength Concrete," Journal of Civil Engineering (IEB), Vol. 37, No.1, pp.53-63.

9. AL-Hassani, H.M.; Khalil, W.I.; and Danha, L.S., 2014, "Mechanical Properties of Reactive Powder Concrete with Various Steel Fiber and Silica Fume Contents," ACTA Tehnica Corviniensis-Bulletin of Engineering, Vol. VII, No.1, pp.47-58.

10. Habel, K.; Viviani, M.; Denarié, E.; and Brühwiler, E., 2006, "Development of the Mechanical Properties of an Ultra-High Performance Fiber Reinforced Concrete (UHPFRC)," Cement and Concrete Research, Vol. 36, pp. 1362-1370.

11. Jooss, M., 2001, "Leaching of Concrete under Thermal Influence," Otto-Graf-Journal, Vol. 12, pp.51-68.

12. Matte, V., and Moranville, M., 1999, "Durability of Reactive Powder Composites: Influence of Silica Fume on the Leaching Properties of Very Low Water/Binder Pastes," Cement and Concrete Composites, Vol. 21, pp. 1-9.

13. Orgass, M., and Klug, Y., 2004, "Steel Fiber Reinforced Ultra-High Strength Concretes," Ph.D. thesis, University of Applied Sciences Leipzig, September, (LACER), No.9.

14. Gao, R.; Stroeven, P.; and Hendriks, C.F., 2005, "Mechanical Properties of Reactive Powder Concrete Beams," ACI Special Publication, Vol. 228, No.79, pp. 1237-1252.

15. Warnock, R., 2005, "Short-Term and Time- Dependent Flexural Behavior of Steel-Fiber Reinforced Reactive Powder Concrete Beams," Ph.D. Thesis, University of New South Wales, p.201.

16. Hegger, J., and Bertram, G., 2008, "Shear Carrying Capacity of Ultra-High Performance Concrete Beams," Tailor Made Concrete Structures, pp. 341-347.

17. Reeves, E., 2004, "Structural Reliability of Ultra-High Performance Concrete in Flexure," M.Sc. Thesis, Faculty of the Fritz J. and Dolores H. Russ, College of Engineering and Technology, Ohio University, USA.

18. Yang, I.H.; Joh, C.; and Kim, B.S., 2010, "Structural Behavior of Ultra High Performance Concrete Beams Subjected to Bending," Engineering Structures Journal, Vol. 32, pp. 3478-3487.

19. Maroliya, M.K., 2012, "Behavior of Reactive Powder Concrete in Direct Shear," IOSR Journal of Engineering (IOSRJEN), Vol. 2, No.9, pp. 76-79. (www.iosrjen.org)

20. Meleka, N.N., 1995, "Nonlinear Analysis of Flat Slabs," Ph. D. thesis, Menoufia Univ., Egypt.

21. E.S.S. 4756-1/2009, 2009, "Ordinary Portland Cement," Egyptian Standard Specification, Egypt.

22. E.C.P. 203/2007, 2007, "Design and Construction for Reinforced Concrete Structures," Egyptian Code of Practice, Research Centre for Houses Building and Physical Planning, Cairo, Egypt.

23. ASTM C 494-03, 2003, "Chemical Admixtures, American Society for Testing and Materials (ASTM)," ASTM International, Philadelphia, USA.

24. E.S.S. 1899-1, 2006, "Additives," Egyptian Standard Specification, Egypt.

25. Meleka, N.N.; Bashandy A.A.; and Arab, M.A., 2013, "Ultra High Strength Concrete Using Economical Materials," International Journal of Current Engineering and Technology IJCET, International Press Corporation INPRESSCO, India, Vol. 3, No.2, pp. 393-402.

26. Arab, M.A., "Behavior of Reinforced Reactive Concrete Beams Cast Using North Sinai Materials," Ph. D. thesis, Menoufia Univ., Menoufia, Egypt, 2012. 
27. Lee, M.G.; Kan, Y.C.; and Chen, K.C., 2006, "A Preliminary Study of RPC for Repair and Retrofitting Materials," Journal of the Chinese Institute of Engineers, Vol. 29, No.6, pp.1099-1103.

28. Lee, M.G.; Wang, Y.C.; and Chiu, C.T., 2007, "A Preliminary study of Reactive Powder Concrete as a New Repair Material," Construction and Building Materials, Vol. 21, pp.182-189.

29. Meleka, N.N.; Tayel, M.A.; Soliman, M.H.; and Emam, E.A., 2003, "Finite Element Analysis of Steel Fiber Reinforced Concrete Structures," Tenth International colloquium on Structural Geotechnical Engineering , Ain Shams University, Cairo.

30. Meleka, N.N.; Tayel, M.A.; Heiza, K.M.; and Badawi, W.A., 2007, "Finite Element Analysis of Self Compact Concrete Beams Reinforced by FRP Bars," Sixth Conference of Egyptian Rural Development Menoufia University, Faculty of Engineering, Shebin El - Kom, Egypt.

31. Rashid, M.A., and Mansur, M.A., 2005, "Reinforced High-Strength Concrete Beams in Flexure," ACI Structural Journal, Vol. 102, No.3, pp.462-471.

32. Bashandy, A.A., 2013, "Influence of Elevated Temperatures on the Behavior of Economical Reactive Powder Concrete", Journal of Civil Engineering Research (ISSN: 2163-2316), Scientific and Academic Publishing SAP, USA. 